\title{
KETERANCAMAN BAHASA ROSWAR: ANALISIS DAYA HIDUP BAHASA
}

Threateness of Roswar's Language: Analysis of Language Vitality

\author{
Santy Yulianti ${ }^{1}$ dan Winci Firdaus ${ }^{2}$ \\ ${ }^{1,2}$ Badan Pengembangan dan Pembinaan Bahasa \\ wincifirdaus1@gmail.com
}

Naskah Diterima Tanggal 30 November 2019-Direvisi Akhir Tanggal 21 Oktober 2020-Disetujui Tanggal 29 November 2020 doi: https://doi.org/10.26499/rnh.v9i2.2942

\begin{abstract}
Abstrak
Tulisan ini merupakan hasil penelitian vitalitas bahasa Roswar di desa Waprak dan Nordiwar, Distrik Roswar, Kabupaten Teluk Wondama, Provinsi Papua Barat. Penelitian ini bertujuan mendeskripsikan vitalitas bahasa di Papua/Papua Barat. Cakupan penelitian ini didasarkan pada teori-teori sosiolinguistik khususnya yang berkaitan dengan vitalitas bahasa dan bahasa terancam punah. Penggunaan bahasa pada ranah/ekspresi tulis, penggunaan bahasa pada ranah keagamaan, dan penggunaan bahasa pada ranah pendidikan sebagian besar berada pada tingkat mengalami kemunduran. Vitalitas bahasa yang berada pada tingkat terancam adalah penggunaan bahasa pada ranah transaksi. Vitalitas bahasa Roswar berdasarkan nilai P (P-value) yang menerangkan keterkaitan variabel-variabel dalam tiap indeks yang dibandingkan berada di ranah mobilitas informan pada posisi relatif kota-desa, penggunaan bahasa pada ranah keluarga, penggunaan bahasa pada ranah/ekspresi tulis, penggunaan bahasa untuk mengungkapkan ekspresi perasaan, penggunaan bahasa pada ranah keagamaan, dan penggunaan bahasa pada ranah pemerintahan.
\end{abstract}

Kata-kata Kunci: vitalitas bahasa, bahasa Roswar, bahasa terancam punah

\begin{abstract}
Roswar language is one of the languages in West Papua which has less than 5000 native speakers, so this language vitality study is needed to measure the vitality of the Roswar language. This paper is the result of research on the vitality of the Roswar language in Waprak and Nordiwar Villages, Roswar District, Teluk Wondama Regency, West Papua Province. This study aims to describe the language vitality in Papua/West Papua. The scope of this research is based on sociolinguistic theories, especially those related to the vitality of language and endangered languages. The use of language in the written domain/expression domain, use of language in the religion domain, and the use of language in the education domain are mostly at a level of decline. Language vitality which is at a threatened level is the use of language in the transactions domain. The vitality of Roswar language is based on the $P$ value ( $P$-value) which explains the relationship between the variables in each index compared to the mobility of the informants in the relative urban-rural position, the use of language in the family domain, the use of language in the written expression domain, the use of language to express expression of feelings, use of language in the religion domain, and use of language in the government domain.
\end{abstract}

Keywords: language vitality, Roswar language, endangered language

How to Cite: Yulianti, Santi dan Winci Firdaus. (2020). Keterancaman Bahasa Roswar: Analisis Daya Hidup Bahasa. Ranah: Jurnal Kajian Bahasa. 9(2). 358-373. doi: https://doi.org/10.26499/rnh.v9i2.2942 


\section{PENDAHULUAN}

Bahasa daerah di Indonesia, menurut data peta bahasa Badan Bahasa (2018), berjumlah 652 dengan 384 bahasa berada di Papua dan Papua Barat, edangkan menurut data Ethnologue (2013), berjumlah 719 dengan 707 bahasa yang masih hidup dan 12 bahasa telah punah. Dari 707 bahasa yang hidup, 701 masih asli dan 6 merupakan bahasa gabungan (baru). Terlebih lagi, 18 bahasa merupakan bahasa formal/institusi, 81 bahasa yang sedang berkembang, 272 bahasa yang terancam, dan 79 bahasa yang sekarat.

Aksara menjadi kekuatan sebuah bahasa dapat bertahan dan memiliki prestise diantara bahasa lainnya. Bahasa-bahasa minoritas masih bertahan setidaknya karena mereka sudah mengenal aksara, tetapi tidak menutup kemungkinan akan tergeser juga oleh bahasa Indonesia. Bahasa-bahasa di Papua dan Papua Barat sebagian besar tidak mengenal aksara (Ethnologue, 2013, pp. 441-442).

SIL mengidentifikasi bahasa Roswar sebagai bahasa War, Meosar dengan populasi 250 jiwa pada tahun 1993 (R.Doriot). Bahasa War/Meosar terletak di Pulau Meoswar, Teluk Cendrawasih Barat, Papua Barat. Status bahasa kuat (vigorous) dan termasuk dalam rumpun Austronesi, Malayo-Polynesia, Central-Eastern Malayo-Polynesian, Eastern MalayoPolynesian, South Halmahera-West New Guinea, West New Guinea, Teluk Cenderawasih, Biak. Agama yang mereka anut mayoritas adalah Kristen. (sumber: https://www.ethnologue.com/language/mvx)

Data bahasa yang terancam punah di Kampung Meoswar (Roswar), Pulau Meoswar (Roswar), Kabupaten Manokwari, Provinsi Papua Barat yang diteliti adalah salah satu bahasa yang belum diidentifikasi oleh Badan Bahasa. Bahasa yang didata merupakan bahasa yang penuturnya sedikit. Bahasa yang berpenutur sedikit cenderung memasuki tahap bahasa yang hampir punahsehingga perlu dilakukan pendokumentasian.

Kajian mengenai bahasa-bahasa yang ada di Papua Barat sebagian besar berkaitan dengan konstruksi bahasa seperti yang disampaikan oleh Donohue (Donohue, 2011) yang menulis tentang konstruksi bahasa-bahasa di Papua Barat dan Sawaki (2019) yang juga menyampaikan tentang bahasa-bahasa di tanah Papua. Kajian vitalitas yang disampaikan Bowern (2017) berkaitan dengan kajian vitalitas yang dilakukan Salikoko yang bermanfaat untuk pemertahanan bahasa dan revitalisasi. Selain itu, Sawaki (2019) mengemukakan bahwa tanah Papua, baik Provinsi Papua maupun Papua Barat di Indonesia, merupakan wilayah linguistik paling beragam yang memiliki jumlah bahasa asli terbanyak di Indonesia. Bahasa tanah Papua terbagi dalam dua kelompok besar, yaitu bahasa Austronesia dan non- 
Austronesia (dikenal sebagai Papua). Kedua kelompok linguistik besar tersebut menyumbangkan ciri kebahasaan yang beragam mulai dari sistem fonologis, kata, frase, klausa dan struktur kalimat, serta keragaman struktur semantik dan pragmatis. Keragaman linguistik juga ditentukan oleh kontak sejarah bahasa di wilayah yang telah berlangsung selama berabad-abad, terutama di wilayah Jayapura dan Kepala Burung New Guinea. Donohue (2011) menyampaikan secara linguistik historis dan tipologi bahasa-bahasa di Papua digolongkan dalam dua kelompok besar yaitu bahasa-bahasa Austronesia dan nonAustronesia. Bahasa Austronesia lebih dikenal dengan tipologi struktur klausa yaitu SPO. Sedangkan, bahasa non-Austronesia atau lebih dikenal dengan istilah bahasa Papua memiliki tipologi struktur klausa SOP. Struktur klausa ini merupakan dasar yang membedakan bahasabahasa kelompok Austronesia dan non-Austronesia (Papua). Salikoko Mufwene's (2017) "language vitality" menurut Bowern berkisar di banyak topik yang berkaitan dengan bahasa terancam dan hilang (LEL). Bowern (2017) setuju bahwa ahli bahasa memang membutuhkan teori tentang alasan munculnya LEL jika kita ingin efektif dalam membantu komunitas dengan pemeliharaan dan revitalisasi bahasa. Bowern berpendapat bahwa ada literatur penting tentang kehilangan bahasa dan revitalisasi bahasa serta reklamasi. Bowern berpendapat bahwa terdapat alasan kuat untuk percaya bahwa bahaya bahasa minoritas pribumi layak dipertimbangkan sebagai kategori LEL yang berbeda.

Penelitian ini bertujuan mendeskripsikan vitalitas bahasa di Papua/Papua Barat. Penelitian ini dibatasi pada masalah vitalitas bahasa Meoswar (Roswar) dan pendokumentasian bahasa yang ada di desa Waprak dan Nordiwar, Distrik Roswar, Kabupaten Teluk Wondama, Provinsi Papua Barat. Cakupan penelitian ini didasarkan pada teori-teori sosiolinguistik, khususnya yang berkaitan dengan vitalitas bahasa dan bahasa terancam punah.

Penelitian ini diharapkan dapat memberikan kontribusi bagi penyelamatan bahasabahasa daerah yang hampir punah. Dengan adanya pendokumentasian bahasa Meoswar (Roswar) ini, diharapkan juga ada pembinaan dan pengembangan terhadap bahasa Meoswar (Roswar).

\section{LANDASAN TEORI}

Penelitian vitalitas bahasa Roswar ini menggunakan kerangka kuantitatif dan kualitatif. Kerangka kuantitatif didasarkan pada teori vitalitas Fishman (2001) dengan cara menghitung vitalitas bahasa Roswar berdasarkan beberapa kategori. Penghitungan indeks 
yang digunakan adalah skala Linkert, yaitu (1) sangat setuju, (2) setuju, (3) ragu-ragu, (4) tidak setuju, dan (5) sangat tidak setuju. Kriteria vitalitas bahasa yang ditetapkan Badan Bahasa berdasarkan teori Fishman (2001) dan Unesco (2011) adalah (1) sangat kritis, (2) sangat terancam, (3) terancam, (4) mengalami kemunduran, (5) kondisi stabil, mantap, tetapi terancam punah, dan (6) aman. Kriteria vitalitas bahasa diukur berdasarkan nilai rerata, yaitu

(1) sangat terancam $(0.0--0.2)$;

(2) terancam $(0.21-0.4)$;

(3) mengalami kemunduran $(0.41-0.6)$;

(4) stabil, mantap, tetapi berpotensi mengalami kemunduran $(0.61-0.8)$; dan

(5) aman $(0.81-1)$.

Kerangka kualitatif didasarkan pada pemikiran Moseley (2007), Fishman (2001), dan Crystal (2000) yang berkaitan dengan faktor-faktor penyebab keterancaman bahasa dan bagaimana penanggulangannya.

Unesco membahas vitalitas bahasa dengan berbagai sudut pandang dari Moseley (2007), Grimes (2001), dan Crystal (2000) dan (2003). Unesco mengutip kriteria Moseley (2007) yang menggarisbawahi kategori keterancaman bahasa dengan

1. jumlah penutur yang masih hidup;

2. usia rerata penutur asli yang masih fasih menggunakan bahasanya; dan

3. persentase generasi muda yang fasih berbahasa daerahnya.

Bahasa akan dipertimbangkan terancam jika anak-anak dalam komunitas tersebut pasif berbahasa ibunya. Mereka hanya memahami bahasanya, tetapi tidak mampu berbicara dengan fasih. Bahasa tersebut kemudian akan hilang di generasi anak-anak mereka. Unesco's Atlas of the World's Languages in Danger mengategorikan 2.500 bahasa dalam lima tingkat keterancaman, yaitu: rentan, terancam, sangat terancam, sangat terancam sekali, dan punah. Tingkatan rentan jika anak-anak berbicara bahasa ibunya hanya di ranah keluarga atau rumah saja. Tingkatan terancam jika anak-anak tidak lagi belajar bahasa ibu mereka di rumah. Tingkatan sangat terancam jika bahasanya hanya digunakan oleh orang tua dan generasi tua saja. Tingkatan sangat terancam sekali jika penuturnya hanya generasi tua saja dan digunakan hanya sebatas frasa/klausa.

Gerrit J. Dimmendaal dan F. K. Erhard Voeltz (2007) dalam Encyclopedia of the World's Endangered Languages (Routledge Language Family Series) mengelompokkan bahasa-bahasa di Papua dalam "Papuan Languange" dengan rumpun Austronesia. Bahasabahasa Austronesia menempati sebagian besar wilayah Papua Nugini. Di bagian barat, bahasa 
tersebut menempati Pulau Timor, Alor,Pantar, dan bagian utara Halmahera. Di bagian timur, bahasa Austronesia menempati pulau-pulau di New Britain, Irlandia Barum dan Bougainville. Ada juga bahasa-bahasa Papua yang menempati rantai Pulau Solomon dan Kepulauan Santa Cruz di bagian timur Pulau Solomon. (2007, p. 449)

Bahasa-bahasa Papua diyakini Gerrit J. Dimmendaal and F. K. Erhard Voeltz (2007) memiliki karakteristik tersendiri. Dari tingkat fonologi, konsonan 1 dan $\mathrm{r}$ contohnya, memiliki fonem yang terpisah. Pembedaan nada secara fonemis dalam berbagai bahasa, begitu pula dalam bahasa-bahasa di filum Trans-Nugini. Kelas kata nomina bersatu dengan kelas kata lain yang menghasilkan makna tertentu. Penanda objek, subjek, dan verba sangat memengaruhi imbuhan yang digunakan dalam nomina. Struktur gramatikal lebih rumit lagi, khususnya pada bahasa-bahasa di Trans-Nugini, Tiricelli, dan wilayah Papua timur. Verba penanda kalimat di tengah ataupun di akhir sangatlah bervariatif. Dengan kata lain, beberapa verba dalam kalimat, persona, dan subjek hanya ditandai dengan verba terakhir, sementara verba kalimat medial diberi imbuhan yang menandakan waktu, keadaan, dan sebagainya. Sebagian besar bahasa di Papua memiliki susunan subjek-objek-verba. Bahasa-bahasa di daratan Papua memiliki sistem numerik tersendiri, contohnya satu, dua, dua-satu untuk tiga, dua-dua untuk empat dan sebagainya. Selain itu, sistem numerik juga dikaitkan dengan anggota tubuh yang hitungannya bisa mencapai tiga puluh, seperti ujung hidung untuk angka tertentu. (2007, p. 433)

Keterancaman sebuah bahasa dapat diperlambat dengan memperhatikan perilaku negatif dari pemerintah terhadap bahasa-bahasa lokal. Di Papua, penutur bahasa asli dari bahasabahasa minoritas tidak diberikan ruang atau tempat di ranah-ranah pemerintahan dan administratif sehingga prestise yang mereka pegang sebagai identitas mereka terkikis. (2007, p. 461)

Crystal (2000) mengemukakan dalam Language Death bahwa bahasa akan selalu mati. Sebagai bagian dari budaya, bahasa akan muncul dan tenggelam. Contohnya pada zaman kuno, Bithinian, Sisilian, Phrygian, Paphagonian, Etruscan, Sumerian, Elamite, Hittite dan banyak bahasa punah lainnya yang dituturkan di Eropa dan sebagian Asia. Bahasa pada dasarnya akan mati jika semua penuturnya telah tiada. Banyak bahasa masuk dalam kategori terancam (endagered), hampir punah (moribund), ataupun punah (extinct) sebagai hasil dari perubahan pada penuturnya. Faktor perubahan/bencana alam tidak dapat dipungkiri telah memberikan pengaruh besar pada pengguna bahasa. Komunitas-komunitas kecil akan dengan mudah tersapu oleh gempa bumi, angin topan, badai, banjir, gunung meletus, dan sebagainya. 
Dicontohkan pada tahun 1998 di pantai Provinsi E. Saundaun, Papua Nugini diterjang gempa berkekuatan 7.1 SR dan mengakibatkan 2.200 korban jiwa yang berada di wilayah Sisssano, Warupu, Arop, dan Malol. Dikutip Crystal dari SIL (1996), sebagian besar suku Arop, Warupu, Sissano, dan Malol terkena dampak yang sangat besar atas kejadian ini. Mereka yang selamat akan mengungsi ke tempat lain dan akan beradaptasi dengan komunitas yang baru. Dengan kata lain, bahasa yang awalnya mereka gunakan akan diganti dengan bahasa yang banyak digunakan di tempat baru (2000, p. 68).

Selain bencana alam, kondisi ekonomi dan iklim juga menjadi penyebab keterancaman sebuah bahasa. Kerusakan kentang di Irlandia (yang disebabkan oleh biri-biri kentang pada 1845-6) menghasilkan 1 juta kematian antara 1845 dan 1851 serta awal periode panjang emigrasi; populasi 8 juta pada 1841 telah menjadi 6,5 juta padasatu dekade kemudian. Dampaknya paling besar di masyarakat pedesaan dan di sinilah Irlandia secara kasar menyatakan bahwa kelaparan pasti mempercepat penurunan komunitas di Irlandia pada saat itu (2000, p. 71).

Crystal (2003) meyakini adanya cara atau jalan untuk membangkitkan kembali bahasa yang hampir mati/punah. Pertama, ia yakin bahwa teori revitalisasi, yaitu menggiatkan kembali penggunaan bahasa ibu di ranah rumah dan tetangga "An endangered language will progress if it's speakers increase their prestige within the dominant community". Crystal percaya bahwa prestise akan datang ketika orang-orang mengenalimu sebagai bagian dari komunitasmu. Kedua, ia meyakini faktor ekonomi juga berpengaruh, "An endangered language will progress if its speakers increase their wealth relative to the dominant community". Faktor ekonomi dalam hal ini menyangkut kemakmuran sebuah komunitas, mulai dari kehidupan mereka, kegiatan perekonomian yang terus maju, ataupun adanya sisi pariwisata dari komunitas tersebut yang dapat dijual.

Ketiga, Crystal berkeyakinan bahwa kekuatan komunitas bahasa terancam punah harus mampu bersaing dengan komunitas bahasa mayoritas, "An endangered language will progress if its speakers increase their legitimate power in the eyes of the dominant community". Dekade penutupan abad kedua puluh melihat bahasa pribumi di banyak bagian dunia yang diuntungkan dari tren di publik opini yang menunjukkan peningkatan simpati terhadap budaya dan linguistik hak.

Keempat, kepedulian akan pendidikan menjadi faktor penting dalam membangkitkan bahasa yang hampir punah, "An endangered language will progress if its speakers have a 
strong presence in the educational system". Mengetahui sesuatu tentang sejarah bahasa, cerita rakyat, dan sastra dapat menjadi jaminan yang besar.

Kelima adalah literasi. Komunitas bahasa terancam punah akan terselamatkan jika mereka mengenal aksara (literasi), "An endangered language will progress if its speakers can write their language down". Hanya karena bahasa yang dituliskan, tidak otomatis berarti itu akan bertahan, walaupun terbukti dari banyak bahasa punah zaman klasik yang kita ketahui hanya melalui catatan tertulis mereka. Namun, begitu bahasa melewati tahap di mana bahasa tersebut dapat ditransmisikan antar generasi sebagai bahasa pertama rumah, masa depannya jauh lebih terjamin jika bisa tertulis.

Keenam adalah teknologi, "An endangered language will progress if its speakers can make use of electronic technology". Sebuah komunitas bahasa akan bertahan lebih lama jika dapat mengembangkan bahasanya dalam ranah teknologi. Ada banyak hal yang harus dilakukan, misalnyapengembangan perangkat lunak menjadi lebih multibahasa. Keenam postulat Crytal (2003) tersebut merupakan langkah tercepat yang dapat dilakukan dari sekian banyak cara untuk menghidupkan kembali bahasa yang hampir punah (2003, pp. 134-144).

\section{METODOLOGI PENELITIAN}

Sesuai dengan metode pengumpulan data kuantitatif dan kualitatif yang disampaikan Creswell (2014), pengumpulan data dilakukan dengan perekaman dan wawancara mendalam. Pengumpulan data kuantitatif dilakukan dengan menjaring responden sebanyak 72 orang dan mengisi kuisioner sesuai arahan peneliti yang dilakukan di Distrik Roswar, Kabupaten Teluk Wondama, Provinsi Papua Barat. Data dikumpulkan dan kemudian dientri ke sistem dengan menggunakan program SPSS. Pengentrian data terdiri atas data diri responden, kategori vitalitas bahasa berdasarkan ranah-ranah, dan nilai dari tiap jawaban.

Data yang telah diklasifikasikan diperbandingkan sebelas indikator dengan karakteristik responden. Kesebelas indikator tersebut adalah

1. mobilitas informan pada posisi relatif kota-desa;

2. kedwibahasaan informan;

3. penggunaan bahasa antargenerasi;

4. penggunaan bahasa pada ranah keluarga;

5. penggunaan bahasa pada ranah transaksi;

6. penggunaan bahasa pada ranah/ ekspresi tulis;

7. penggunaan bahasa untuk mengungkapkan ekspresi perasaan; 
8. penggunaan bahasa pada ranah keagamaan;

9. penggunaan bahasa pada ranah pemerintahan;

10. penggunaan bahasa pada ranah pendidikan; dan

11. sikap bahasa (kebanggaan dan kesetiaan bahasa).

Sedangkan karateristik responden yang diperbandingkan adalah usia, suku bangsa, pendidikan, pekerjaan, dan status pernikahan dengan menggunakan indeks. Karaterisitik ini dipilih karena sangat memengaruhi penggunaan bahasa Roswar sehari-hari.

\section{HASIL DAN PEMBAHASAN}

Pulau Mioswar termasuk dalam wilayah Distrik Wamesa. Pulau ini memiliki sumber air panas yang mangandung belerang tanpa kadar garam dan mengalir ke pantai yang berjarak sekitar 300 meter dari sumber air panas. Di pulau ini juga terdapat gua bersejarah dan peninggalan masyarakat Numfor di mana di dalamnya terdapat tengkorak manusia, piringpiring antik, dan peti berukir.

Selain menikmati sumber air panas dan mengunjungi gua bersejarah tersebut, kegiatan lain yang dapat dilakukan di pulau ini adalah menyelam menikmati keindahan alam bawah laut, menikmati air terjun, dan pengamatan satwa khususnya kelelawar.

Distrik Roswar terletak di Pulau Mios Waar, merupakan salah satu pulau yang termasuk dalam lingkungan Taman Nasional Teluk Cenderawasih. Distrik ini terbentuk pada 2006 dan terdiri atas empat kampung, yaitu

1. Kampung Waprak* (sebelum menjadi distrik, kampung ini bernama Saref);

2. Kampung Nordiwar*;

3. Kampung Yomber; dan

4. Kampung Syeiwar.

Sebelum menjadi sebuah distrik, Roswar terdiri atas dua kampung, yakni Waprak dan Yomber yang termasuk dalam wilayah Distrik Wamesa. Akan tetapi, setelah menjadi distrik, Kampung Waprak dimekarkan menjadi dua kampung: Waprak dan Nordiwar, terletak di bagian barat Pulau Mios War. Kampung Yomber juga dimekarkan menjadi dua kampung: Yomber dan Syeiwar, terletak di bagian timur Pulau Mios War.

Berdasarkan data dari aparat kampung, penduduk Kampung Waprak berjumlah 320 jiwa dengan rincian sebagai berikut. Penduduk laki-laki 78 orang, perempuan 67 orang, anakanak laki-laki 82 orang, anak-anak perempuan 93 orang. Sementara itu, Kampung Nordiwar berjumlah 149 jiwa dengan laki-laki 77 orang dan perempuan 72 orang.Sebagian besar mata 
pencaharian di kedua desa tersebut adalah nelayan, petani, dan pegawai negeri. Sebagai besar mengenyam pendidikan kedua desa tersebut hanya sampai Sekolah Dasar (SD).

Berikut adalah hasil penghitungan rerata indeks tiap indikator yang digunakan dalam mengukur vitalitas bahasa Roswar.

Tabel 1.

Nilai Rerata Antarindeks

\begin{tabular}{clcc}
\hline \multicolumn{5}{c}{ Deskripsi Kelompok } \\
\hline No & \multicolumn{4}{c}{ Jumlah } & Rerata Indeks \\
\hline 1 & Mobilitas informan pada posisi relatif kota-desa & 72 & 0.66 \\
\hline 2 & Kedwibahasaan informan & 72 & 0.70 \\
\hline 3 & Penggunaan bahasa antargenerasi & 72 & 0.71 \\
\hline 4 & Penggunaan bahasa pada ranah keluarga & 72 & 0.72 \\
\hline 5 & Penggunaan bahasa pada ranah transaksi & 72 & 0.39 \\
\hline 6 & Penggunaan bahasa pada ranah ekspresi tulis & 72 & 0.44 \\
\hline 7 & Penggunaan bahasa untuk mengungkapkan ekspresi & 72 & 0.68 \\
\hline 8 & Perasaan & 72 & 0.55 \\
\hline 9 & Penggunaan bahasa pada ranah pemerintahan & 72 & 0.66 \\
\hline 10 & Penggunaan bahasa pada ranah pendidikan & 72 & 0.59 \\
\hline 11 & Sikap bahasa (kebanggaan dan kesetiaan bahasa) & 72 & 0.73 \\
\hline & Total & 72 & 0.62 \\
\hline
\end{tabular}

Pada Tabel 1 di atas terdapat sebelas ranah penggunaan yang dideskripsikan mengenai bahasa Roswar. Ranah pertama adalah mobilitas informan dari kota ke desa atau sebaliknya dengan nilai rerata (mean) 0,66. Nilai ini berarti vitalitas bahasa berada pada keadaan stabil, mantap, tetapi mengalami kemunduran. Ranah kedua adalah penggunaan bahasa pada ranah keluarga dengan nilai rerata (mean) 0,70 . Nilai ini berarti vitalitas bahasa berada pada keadaan stabil, mantap, tetapi mengalami kemunduran. Ranah ketiga adalah penggunaan bahasa antargenerasi dengan nilai rerata (mean) 0,71 . Nilai ini berarti vitalitas bahasa berada pada keadaan stabil, mantap, tetapi mengalami kemunduran. Ranah keempat adalah penggunaan bahasa pada ranah keluarga dengan nilai rerata (mean) 0,72 . Nilai ini berarti vitalitas bahasa berada pada keadaan stabil, mantap, tetapi mengalami kemunduran. Ranah kelima adalah penggunaan bahasa pada ranah transaksi dengan nilai rerata (mean) 0,39 . Nilai ini berarti vitalitas bahasa berada pada keadaan terancam. Ranah keenam adalah penggunaan bahasa pada ranah tulis dengan nilai rerata (mean) 0,44 . Nilai ini berarti vitalitas bahasa mengalami kemunduran. Ranah ketujuh adalah penggunaan bahasa untuk mengungkapkan perasaan dengan nilai rerata (mean) 0,68. Nilai ini berarti vitalitas bahasa berada pada keadaan stabil, mantap, tetapi mengalami kemunduran. Ranah kedelapan adalah penggunaan 
bahasa antargenerasi dengan nilai rerata (mean) 0,55. Nilai ini berarti vitalitas bahasa mengalami kemunduran. Ranah kesembilan adalah penggunaan bahasa pada ranah pemerintahan dengan nilai rerata (mean) 0,66 . Nilai ini berarti vitalitas bahasa berada pada keadaan stabil, mantap, tetapi mengalami kemunduran. Ranah kesepuluh adalah penggunaan bahasa pada ranah pendidikan dengan nilai rerata (mean)0,73. Nilai ini berarti vitalitas bahasa berada pada keadaan stabil, mantap, tetapi mengalami kemunduran. Ranah kesebelas adalah sikap bahasa dengan nilai rerata (mean) 0,62 . Nilai ini berarti vitalitas bahasa berada pada keadaan stabil, mantap, tetapi mengalami kemunduran.

\section{VITALITAS BAHASA ROSWAR SECARA STATISITIK}

Dalam pengujian, kita membandingkan nilai $\mathrm{P}(P$-value $)$ ini dengan tingkat signifikansi pengujian $\alpha=0,05$, dengan kriteria tolak $H_{0}$ jika $P$-value $<\alpha$, dan terima HO jika $P$-value $>\alpha$. Nilai P merupakan angka signifikansi keterkaitan dua indikator yang dibandingkan. Jika hasil pengujian kurang dari 0.05 maka keterkaitannya tidak signifikan, dan sebaliknya jika hasil pengujiannya lebih dari 0,05 maka keterkaitannya signifikan. Berikut adalah tabel perbandingan beberapa indikator.

Tabel 2.

Nilai Keterkaitan $(P$-value $)$ Berdasarkan Usia

\begin{tabular}{|c|c|c|c|}
\hline & & & \\
\hline Mean & $<25$ Tahun & $\begin{array}{c}26-50 \\
\text { Tahun }\end{array}$ & P-value \\
\hline Mobilitas informan pada posisi relatif kota-desa & 37.58 & 27.79 & 0.032 \\
\hline Kedwibahasaan informan & 27.05 & 32.93 & 0.217 \\
\hline Penggunaan bahasa antargenerasi & 21.35 & 35.71 & 0.003 \\
\hline Penggunaan bahasa pada ranah keluarga & 18.48 & 37.11 & 0.000 \\
\hline Penggunaan bahasa pada ranah transaksi & 31.30 & 30.85 & 0.900 \\
\hline Penggunaan bahasa pada ranah ekspresi tulis & 28.68 & 32.13 & 0.331 \\
\hline Penggunaan bahasa untuk mengungkapkan ekspresi perasaan & 20.75 & 36.00 & 0.002 \\
\hline Penggunaan bahasa pada ranah keagamaan & 24.13 & 34.35 & 0.027 \\
\hline Penggunaan bahasa pada ranah pemerintahan & 26.33 & 33.28 & 0.144 \\
\hline Penggunaan bahasa pada ranah pendidikan & 34.10 & 29.49 & 0.321 \\
\hline Sikap bahasa (kebanggaan dan kesetiaan bahasa) & 32.70 & 30.17 & 0.599 \\
\hline
\end{tabular}

Berdasarkan Tabel 2, nilai P (P-value) berdasarkan usia yang memiliki perbedaan $(<0.05)$ adalah mobilitas informan pada posisi relatif kota-desa, penggunaan bahasa antargenerasi, penggunaan bahasa pada ranah keluarga, dan penggunaan bahasa untuk mengungkapkan ekspresi perasaan, serta penggunaan bahasa pada ranah keagamaan. Sedangkan nilai P (P-value) berdasarkan usia yang memiliki persamaan $(>0.05)$ adalah kedwibahasaan informan, penggunaan bahasa pada ranah transaksi, penggunaan bahasa pada 
ranah/ekspresi tulis, penggunaan bahasa pada ranah pemerintahan, penggunaan bahasa pada ranah pendidikan, dan sikap bahasa (kebanggaan dan kesetiaan bahasa).

Tabel 3.

Nilai KeterkaitanKeterkaitan ( $P$-value $)$ Berdasarkan Suku Bangsa

\begin{tabular}{lcccc} 
Indeks & Mean & Roswar & $\begin{array}{l}\text { Bukan } \\
\text { Roswar }\end{array}$ & $P$-value \\
\hline Mobilitas informan pada posisi relatif kota-desa & & 36.95 & 4.50 & 0.105 \\
\hline Kedwibahasaan informan & 36.46 & 39.50 & 0.884 \\
\hline Penggunaan bahasa antargenerasi & 36.05 & 68.50 & 0.122 \\
\hline Penggunaan bahasa pada ranah keluarga & 36.21 & 57.00 & 0.322 \\
\hline Penggunaan bahasa pada ranah transaksi & 36.63 & 27.50 & 0.569 \\
\hline Penggunaan bahasa pada ranah ekspresi tulis & 36.47 & 38.50 & 0.894 \\
\hline Penggunaan bahasa untuk mengungkapkan ekspresi perasaan & 36.23 & 55.50 & 0.359 \\
\hline Penggunaan bahasa pada ranah keagamaan & 36.68 & 23.50 & 0.514 \\
\hline Penggunaan bahasa pada ranah pemerintahan & 36.61 & 29.00 & 0.714 \\
\hline Penggunaan bahasa pada ranah pendidikan & 36.27 & 52.50 & 0.427 \\
\hline Sikap bahasa (kebanggaan dan kesetiaan bahasa) & 36.06 & 68.00 & 0.128 \\
\hline
\end{tabular}

Berdasarkan Tabel 3, nilai $\mathrm{P}$ (P-value) berdasarkan suku bangsa yang memiliki persamaan $(>0.05)$ terjadi pada semua indeks, yaitu mobilitas informan pada posisi relatif kota-desa, penggunaan bahasa antargenerasi, penggunaan bahasa pada ranah keluarga, dan penggunaan bahasa untuk mengungkapkan ekspresi perasaan, penggunaan bahasa pada ranah keagamaan, kedwibahasaan informan, penggunaan bahasa pada ranah transaksi, penggunaan bahasa pada ranah/ekspresi tulis, penggunaan bahasa pada ranah pemerintahan, penggunaan bahasa pada ranah pendidikan, dan sikap bahasa (kebanggaan dan kesetiaan bahasa).

Tabel 4.

Nilai KeterkaitanKeterkaitan $(P$-value $)$ Berdasarkan Pendidikan

\begin{tabular}{|c|c|c|c|}
\hline \\
\hline Indeks & SD/Tidak & Sekolah & $P$-value \\
\hline Mean & & & \\
\hline Mobilitas informan pada posisi relatif kota-desa & 35.47 & 37.97 & 0.661 \\
\hline Kedwibahasaan informan & 34.61 & 41.20 & 0.265 \\
\hline Penggunaan bahasa antargenerasi & 35.09 & 39.40 & 0.471 \\
\hline Penggunaan bahasa pada ranah keluarga & 37.33 & 31.03 & 0.292 \\
\hline Penggunaan bahasa pada ranah transaksi & 32.84 & 47.80 & 0.001 \\
\hline Penggunaan bahasa pada ranah ekspresi tulis & 34.92 & 40.03 & 0.243 \\
\hline $\begin{array}{l}\text { Penggunaan bahasa untuk mengungkapkan ekspresi } \\
\text { perasaan }\end{array}$ & 36.95 & 32.47 & 0.454 \\
\hline Penggunaan bahasa pada ranah keagamaan & 35.20 & 39.00 & 0.508 \\
\hline Penggunaan bahasa pada ranah pemerintahan & 34.61 & 41.20 & 0.265 \\
\hline Penggunaan bahasa pada ranah pendidikan & 33.54 & 45.17 & 0.046 \\
\hline Sikap bahasa (kebanggaan dan kesetiaan bahasa) & 33.13 & 46.70 & 0.023 \\
\hline
\end{tabular}


Berdasarkan Tabel 4, nilai $\mathrm{P}$ (P-value) berdasarkan pendidikan yang memiliki perbedaan $(<0.05)$ adalah penggunaan bahasa pada ranah transaksi, penggunaan bahasa pada ranah pendidikan, dan sikap bahasa (kebanggaan dan kesetiaan bahasa).

Sedangkan nilai $\mathrm{P}(P$-value $)$ berdasarkan pendidikan yang memiliki persamaan $(>0.05)$ adalah mobilitas informan pada posisi relatif kota-desa, penggunaan bahasa antargenerasi, penggunaan bahasa pada ranah keluarga, penggunaan bahasa untuk mengungkapkan ekspresi perasaan, penggunaan bahasa pada ranah keagamaan, kedwibahasaan informan, penggunaan bahasa pada ranah/ekspresi tulis, dan penggunaan bahasa pada ranah pemerintahan.

Tabel 5.

Nilai KeterkaitanKeterkaitan $(P$-value $)$ Berdasarkan Pekerjaan

\begin{tabular}{|c|c|c|c|}
\hline Indeks & $\begin{array}{l}\text { Tidak } \\
\text { Bekerja }\end{array}$ & Petani/Nelayan & $\begin{array}{c}P- \\
\text { value }\end{array}$ \\
\hline Mobilitas informan pada posisi relatif kota-desa & 31.61 & 31.34 & 0.951 \\
\hline Kedwibahasaan informan & 27.38 & 37.60 & 0.026 \\
\hline Penggunaan bahasa antargenerasi & 27.74 & 37.06 & 0.045 \\
\hline Penggunaan bahasa pada ranah keluarga & 29.41 & 34.60 & 0.264 \\
\hline Penggunaan bahasa pada ranah transaksi & 28.77 & 35.54 & 0.029 \\
\hline Penggunaan bahasa pada ranah ekspresi tulis & 29.09 & 35.06 & 0.072 \\
\hline $\begin{array}{l}\text { Penggunaan bahasa untuk mengungkapkan ekspresi } \\
\text { perasaan }\end{array}$ & 28.82 & 35.46 & 0.154 \\
\hline Penggunaan bahasa pada ranah keagamaan & 31.78 & 31.08 & 0.875 \\
\hline Penggunaan bahasa pada ranah pemerintahan & 32.41 & 30.16 & 0.624 \\
\hline Penggunaan bahasa pada ranah pendidikan & 26.81 & 38.44 & 0.009 \\
\hline Sikap bahasa (kebanggaan dan kesetiaan bahasa) & 26.04 & 39.58 & 0.004 \\
\hline
\end{tabular}

Berdasarkan Tabel 5, nilai P ( $P$-value) berdasarkan pekerjaan yang memiliki perbedaan (< 0.05$)$ adalah kedwibahasaan informan, penggunaan bahasa antargenerasi, penggunaan bahasa pada ranah transaksi, penggunaan bahasa pada ranah pendidikan, dan sikap bahasa (kebanggaan dan kesetiaan bahasa).

Sedangkan nilai $\mathrm{P}$ ( $P$-value $)$ berdasarkan pekerjaan yang memiliki persamaan $(>0,05)$ adalah mobilitas informan pada posisi relatif kota-desa, penggunaan bahasa pada ranah keluarga, penggunaan bahasa untuk mengungkapkan ekspresi perasaan, penggunaan bahasa pada ranah keagamaan, penggunaan bahasa pada ranah/ekspresi tulis, dan penggunaan bahasa pada ranah pemerintahan. 
Tabel 6.

Nilai Keterkaitan $(P$-value $)$ Berdasarkan Status Pernikahan

\begin{tabular}{|c|c|c|c|}
\hline Indeks & Menikah & Belum Menikah & P-value \\
\hline $\begin{array}{r}\text { Mean } \\
\text { Mobilitas informan pada posisi relatif kota-desa }\end{array}$ & 3608 & 4036 & 0589 \\
\hline Kedwibahasaan informan & 37.62 & 26.07 & 0.159 \\
\hline Penggunaan bahasa antargenerasi & 38.27 & 20.07 & 0.028 \\
\hline Penggunaan bahasa pada ranah keluarga & 37.73 & 25.07 & 0.127 \\
\hline Penggunaan bahasa pada ranah transaksi & 36.20 & 39.29 & 0.626 \\
\hline Penggunaan bahasa pada ranah ekspresi tulis & 35.35 & 47.21 & 0.049 \\
\hline $\begin{array}{l}\text { Penggunaan bahasa untuk mengungkapkan ekspresi } \\
\text { perasaan }\end{array}$ & 38.20 & 20.71 & 0.035 \\
\hline Penggunaan bahasa pada ranah keagamaan & 37.97 & 22.86 & 0.058 \\
\hline Penggunaan bahasa pada ranah pemerintahan & 37.23 & 29.71 & 0.359 \\
\hline Penggunaan bahasa pada ranah pendidikan & 35.85 & 42.57 & 0.405 \\
\hline Sikap bahasa (kebanggaan dan kesetiaan bahasa) & 35.74 & 43.57 & 0.344 \\
\hline
\end{tabular}

Berdasarkan Tabel 6, nilai $\mathrm{P}(P$-value $)$ berdasarkan status pernikahan yang memiliki perbedaan $(<0.05)$ adalah penggunaan bahasa antargenerasi, kedwibahasaan informan, dan penggunaan bahasa pada ranah/ekspresi tulis.

Sedangkan nilai P ( $P$-value) berdasarkan status pernikahan yang memiliki persamaan (> 0.05) adalah mobilitas informan pada posisi relatif kota-desa, penggunaan bahasa pada ranah transaksi, penggunaan bahasa pada ranah keluarga, penggunaan bahasa untuk mengungkapkan ekspresi perasaan, penggunaan bahasa pada ranah keagamaan, penggunaan bahasa pada ranah pemerintahan, penggunaan bahasa pada ranah pendidikan, dan sikap bahasa (kebanggaan dan kesetiaan bahasa).

Vitalitas bahasa Roswar berdasarkan nilai P ( $P$-value $)$ yang menerangkan keterkaitan variabel dalam tiap indeks yang dibandingkan berada di ranah mobilitas informan pada posisi relatif kota-desa, penggunaan bahasa pada ranah keluarga, penggunaan bahasa pada ranah/ekspresi tulis, penggunaan bahasa untuk mengungkapkan ekspresi perasaan, penggunaan bahasa pada ranah keagamaan, dan penggunaan bahasa pada ranah pemerintahan.

\section{KETERANCAMAN BAHASA ROSWAR}

Berdasarkan nilai P (P-value) yang dipaparkan tersebut, ranah kehidupan yang berada pada tingkat stabil, mantap, tetapi berpotensi mengalami kemunduran adalah mobilitas penutur, kedwibahasaan informan, penggunaan bahasa antargenerasi, penggunaan bahasa pada ranah keluarga, penggunaan bahasa untuk mengungkapkan ekspresi perasaan, penggunaan bahasa pada ranah pemerintahan, dan sikap bahasa (kebanggaan dan kesetiaan bahasa). 
Penggunaan bahasa pada ranah/ekspresi tulis, penggunaan bahasa pada ranah keagamaan, dan penggunaan bahasa pada ranah pendidikan sebagian besar berada pada tingkat mengalami kemunduran. Vitalitas bahasa yang berada pada tingkat terancam adalah penggunaan bahasa pada ranah transaksi.

Berdasarkan hasil tersebut, postulasi Crystal (2000) dapat digunakan pada ranah-ranah tersebut, yaitu dengan cara

1. Penggunaan bahasa ibu di ranah rumah dan tetangga selalu dilakukan. Aktivitas ini masih dilakukan oleh penutur bahasa Roswar dan harus terus dipertahankan.

2. Mempertahankan pengguna bahasa Roswar untuk lebih aktif dalam pembangunan ekonomi lokal. Dengan demikian, prestise penutur bahasa Roswar akan ikut terjaga juga. Penutur bahasa Roswar lebih aktif lagi menggunakan bahasa ibu mereka ketika bertransaksi dan tidak harus merasa minoritas walaupun bukan bagian dari bahasa mayoritas.

3. Penutur bahasa Roswar diharapkan terus meningkatkan peran serta mereka di ranah pemerintahan dan selalu menggunakan bahasa Roswar jika berada dalam situasi tutur pengguna bahasa yang sama.

4. Ranah pendidikan mendapat perhatian yang kurang sehingga mengakibatkan keberadaan bahasa Roswar tidak dibutuhkan. Oleh karena itu, diperlukan sikap saling mendukung untuk menjadikan bahasa Roswar sebagai salah satu muatan lokal setidaknya di sekolah di wilayah Waprak.

5. Ranah tulis seperti budaya menulis dalam bahasa Roswar harus digiatkan kembali. Hal ini dapat diawali dengan membuat catatan-catatan kecil di rumah dalam bahasa Roswar, ber-SMS/kirim pesan dengan sesama penutur dengan menggunakan bahasa Roswar, ataupun berlatih menulis pengalaman sehari-hari dalam bahasa Roswar.

6. Kemajuan teknologi memberikan peran penting dalam pemertahanan suatu bahasa. Hal ini dimulai oleh generasi muda yang memang lebih dekat dengan dunia teknologi. Generasi muda diharapkan mulai menciptakan gagasan-gagasan yang memberikan sumbangan pada bahasa mereka.

Semua postulasi tersebut akan berjalan dengan baik jika didukung oleh semua pihak. Penutur bahasa Roswar harus memiliki kesadaran pentingnya keberlangsungan bahasa mereka. Pemerintah sebagai pembuat regulasi harus lebih banyak memberikan ruang bagi bahasa Roswar dan penuturnya. Bahasa Moyoritas yang ada di Pulau Meoswar juga harus 
memiliki kesadaran akan pentingnya membina hubungan baik dengan bahasa minoritas, salah satunya bahasa Roswar.

\section{SIMPULAN}

Penelitian vitalitas bahasa Roswar ini dapat ditarik simpulan bahwa vitalitas bahasa Roswar berdasarkan pada sebelas ranah penggunaan yang berbeda, menunjukkan kesamaan kategori vitalitas dalam tiga tingkat, yaitu (1) stabil, mantap, tetapi berpotensi mengalami kemunduran; (2) mengalami kemunduran; dan (3) terancam. Ranah kehidupan yang berada pada tingkat stabil, mantap, tetapi berpotensi mengalami kemunduran adalah mobilitas penutur, kedwibahasaan informan, penggunaan bahasa antargenerasi, penggunaan bahasa pada ranah keluarga, penggunaan bahasa untuk mengungkapkan ekspresi perasaan, penggunaan bahasa pada ranah pemerintahan, dan sikap bahasa (kebanggaan dan kesetiaan bahasa). Penggunaan bahasa pada ranah/ekspresi tulis, penggunaan bahasa pada ranah keagamaan, dan penggunaan bahasa pada ranah pendidikan sebagian besar berada pada tingkat mengalami kemunduran. Vitalitas bahasa yang berada pada tingkat terancam adalah penggunaan bahasa pada ranah transaksi.

Vitalitas bahasa Roswar berdasarkan nilai P ( $P$-value) yang menerangkan keterkaitan variabel dalam tiap indeks yang dibandingkan berada di ranah mobilitas informan pada posisi relatif kota-desa, penggunaan bahasa pada ranah keluarga, penggunaan bahasa pada ranah/ ekspresi tulis, penggunaan bahasa untuk mengungkapkan ekspresi perasaan, penggunaan bahasa pada ranah keagamaan, dan penggunaan bahasa pada ranah pemerintahan. Pemerintah sebagai pembuat regulasi harus lebih banyak memberikan ruang bagi bahasa Roswar dan penuturnya. Bahasa Moyoritas yang ada di Pulau Meoswar juga harus memiliki kesadaran akan pentingnya membina hubungan baik dengan bahasa minoritas, salah satunya bahasa Roswar.

\section{DAFTAR PUSTAKA}

Aritonang, Buha (2016). Kriteria Vitalitas Bahasa Talondo. Ranah: Jurnal Kajian Bahasa, 5(1), 8-24. https://doi.org/10.26499/rnh.v5i1.34

Bowern, C. (2017). Language vitality: Theorizing language loss, shift, and reclamation (Response to Mufwene). Language, 93(4), e243-e253. https://doi.org/10.1353/lan.2017.0068

Creswell, J. W. (2014). Research Design (Qualitative, quantitative, and Mixed Methods Approaches). Los Angeles, London, New Delhi, Singapore, and Washington DC: SAGE.

Crystal, D. (2000). Language death. Cambridge: Cambridge University Press. https://doi.org/10.1017/CBO9781139106856 
Crystal, D. (2003). English as a Global Language. Cambridge: Cambridge University Press. https://doi.org/10.1017/CBO9780511486999

Donohue, M. (2011). A grammar of Maybrat: A language of the Bird's Head Peninsula, Papua Province, Indonesia (review). Oceanic Linguistics, 50(1), 279-283. https://doi.org/10.1353/ol.2011.0011

Ethnologue. (2013). Ethnologue. Retrieved from https://www.ethnologue.com-/language/mvx Firdaus, Winci. (2018). Tekanan Kepunahan Bahasa Suwawa: Analisis Tingkat Daya Hidup Bahasa. Metalingua. 16(2), 307-314. https://doi.org/10.26499/metalingua.v16i2.240

Fishman, A. J. (2001). Can Threatened Languages be Saved? In J. A. Fishman (Ed.), Can Threatened Languages be Saved?. https://doi.org/10.21832/9781853597060

Moseley, C. (2007). Encyclopedia of the world's endangered languages. New York: Routledge Taylor \& Francis Group.

Sawaki, Y. W. (2019). Meneropong Tipologi Bahasa-Bahasa di Papua: Suatu Tinjuan Singkat. Linguistik Indonesia, 36(2), 129-143. https://doi.org/10.26499/li.v36i2.79

Tim Pemetaan. (2018). Bahasa dan Peta Bahasa di Indonesia. Jakarta: Badan Pengembangan dan Pembinaan Bahasa dan Sastra.

Unecco. (2011). Language Vitality and Endangerment Methodological Guideline: Review of Application and Feedback since 2003. Paris. 